\title{
Entrepreneurship and Industry Growth
}

\author{
Mohsen Mehrara ${ }^{1, *}$, Abbas Ali Rezaei ${ }^{2, * *}$ \\ ${ }^{1}$ Faculty of Economics, University of Tehran, Kargar-e-shomali \\ Po Box 14166-6445, Tehran, Iran \\ 2Organization of Economic affairs and Finance In Sistan \& Balouchestan, \\ Foreign Investment Service Center, Po Box 98168-75671, Iran

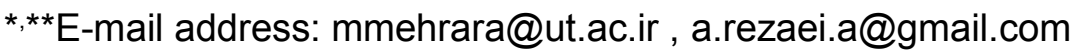

\begin{abstract}
In this paper, we investigate the relation between entrepreneurship and Growth of Value Added in Industrial Sector. For this purpose, we investigated the data related to sistan and Baluchestan Province in the period of 2000 to 2010 by using endogenous growth model. In this model, we set Growth of Value Added in Industrial Sector as a function of entrepreneurship, physical capital and labor based on Cobb-Douglas Form. Estimated elasticity of Growth of Value Added included 0.60, 0.38, and 0.92 as compared to entrepreneurship, physical capital and labor, respectively. They all have high statistical significances. The results indicate positive effect of entrepreneurship and innovation on the Growth of Value Added. In other words, increase of entrepreneurship and innovation coefficient will increase Value Added of Industrial Sector in Sistan and Baluchestan Province. The positive effect of physical capital and labor on the Growth of Value Added is another result of this study.
\end{abstract}

Keywords: Entrepreneurship; Physical Capital; Endogenous Growth Model; Cobb-Douglas Function; Economic Growth

JEL Classification: Z13, O40, R11, P36, Z19

\section{INTRODUCTION}

One of the most important goals of contemporary economics is determining the factors that cause economic growth. Traditional neoclassical theory holds that the economic growth of a country is determined by the supplies of both labor and capital the country possesses and the level of technology present in that country (Todaro and Smith, p.129). Some neoclassical economists have suggested that both knowledge and pro-market government policies also have a significant influence on economic growth (Audretsch and Kielbach, p. 605; Todaro and Smith, p. 130). The level of technology in a given society is heavily dependent on the level of knowledge in that society; this paper will regard these two factors as essentially the same. The established neoclassical factors of economic growth are thus the levels of capital and labor present in a given society, the level of knowledge (or technology) present in that society, and the extent to which the government of that society pursues pro-market government policies. However, this model ignores any direct effect that entrepreneurship may have on economic growth. 
At the end of 1970s, a wave of small businesses and self-employments were created in most of the advanced countries due to changes in the values and tendencies of society as well as demographical changes. Several studies have been made in this regard from 4 viewpoints as the result of deep changes of that. The critical question that has occupied the minds of economists and other policymakers is that why always some countries have high and some other have low economic growths and why some countries are rich and some other are poor. In the recent years, growth models have been somehow changed and other factors such as human capital have been included in them. Most economists put an emphasis on establishment of physical and human capital as the main determinant of economic growth and development. Capital is one of the most important determinants of economic growth. Improvement of the quality of tools and machineries increases labor productivity and in this way it improves welfare as well. But capital has not just a physical aspect. Human capital which is fulfilled in the forms of skills, education, and training may also indicate a better condition of human capital in that country. Therefore, we may consider entrepreneurship and innovation as a replacement for human capital variable.

The present study aims to investigate the relation between entrepreneurship and Growth of Value Added in Industrial Sector. For this purpose, we investigated the data related to sistan and Baluchestan Province in the period of 2000 to 2010 by using endogenous growth model. The main question of this study is that if there is a positive and significant relation between entrepreneurship and innovation and economic growth. On this basis, this article consists of 7 parts. After introduction and in the second part, we explain the concept of entrepreneurship and innovation and the common definitions and meanings for them as well as the method of their measurement and calculation. In the third part, experimental studies made in this regard are dealt with. In the fourth part, Data and Econometric Methodology and the model used in this paper are explained. Experimental data and findings are investigated in the sixth part and finally a summary and conclusion will be provided in the seventh part.

\section{THE CONCEPT OF ENTREPRENEURSHIP}

Entrepreneurship is an ill-defined, multidimensional, concept. The difficulties in defining and measuring the extent of entrepreneurial activities complicate the measurement of their impact on economic performance. Understanding their role in the process of growth requires a framework because there are various intermediate variables or linkages to explain how entrepreneurship influences economic growth. Examples of these intermediate variables are innovation, variety of supply, entry and exit of firms (competition), specific efforts and energy of entrepreneurs, etc. See Figure 1 where also some conditions for entrepreneurship are provided. These conditions include personal traits that lie at the origin of entrepreneurship and cultural and institutional elements (See also Audretsch, Verheul, Thurik and Wennekers. 2002 and Wennekers, Thurik and Uhlaner, 2002).

Despite the long record of investigation of entrepreneurship as well as much effort of researchers, like other concepts of human science, it is difficult and even impossible to provide a certain definition for that. Addressing the evolutionary process of this concept includes interesting points. Several elements such as risk susceptibility, innovation, etc. have been added to the entrepreneurship concept during its evolutionary process. 


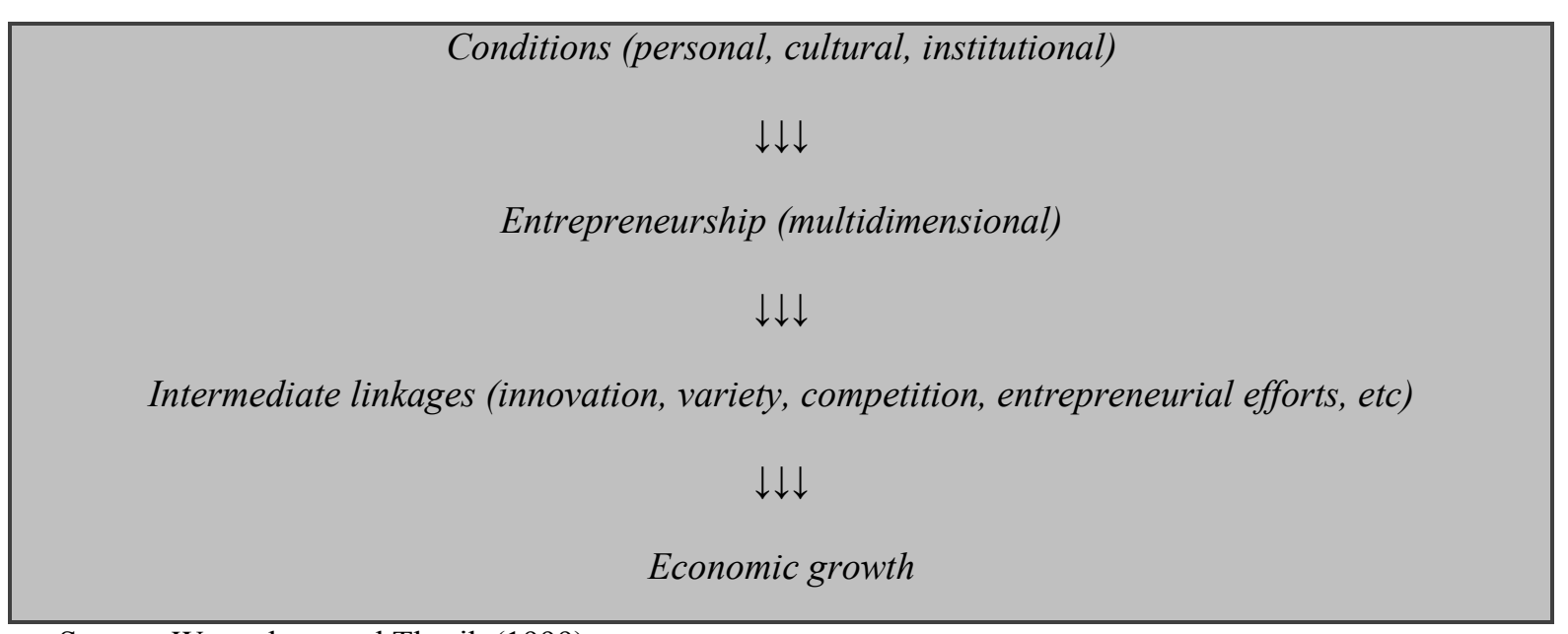

Source: Wennekers and Thurik (1999)

Figure 1. Introductory framework.

The word "Entrepreneurship" has been derived from the French word "Entreprendre" which means "To Undertake". In summary, entrepreneurship is the process of providing value through establishment of a unique complex of resources in order to enjoy opportunities. Entrepreneurship has to do with activities of individual persons. The concept of economic growth is relevant at levels of firms, regions, industries and nations. Hence, linking entrepreneurship to economic growth means linking the individual level to aggregate levels. In order to consider this link we first pay attention to a definition of 'entrepreneurship'. Inspired by Hébert and Link (1989), Bull and Willard (1993) and Lumpkin and Dess (1996), the following definition of entrepreneurship can be proposed: Entrepreneurship is the manifest ability and willingness of individuals, on their own, in teams, within and outside existing organizations to perceive and create new economic opportunities (new products, new production methods, new organizational schemes and new product-market combinations), and to introduce their ideas in the market, in the face of uncertainty and other obstacles, by making decisions on location, form and the use of resources and institutions (Wennekers and Thurik, 1999). Essentially, entrepreneurship is a behavioral characteristic of persons. It should be noted that entrepreneurship is not an occupation and that entrepreneurs are not a well-defined occupational class of persons. Even obvious entrepre neurs may exhibit their entrepreneurship only during a certain phase of their career and/or concerning a certain part of their activities.

Entrepreneurship is not synonymous with small business. Certainly, small firms are an outstanding vehicle for individuals to channel their entrepreneurial ambitions. The small firm is an extension of the individual in charge (Lumpkin and Dess, 1996, p. 138). However, entrepreneurship is not restricted to persons starting or operating an (innovative) small firm. Enterprising individuals in large firms, the so-called 'intrapreneurs' or 'corporate entrepreneurs', undertake entrepreneurial actions as well. In these environments there is a tendency of 'mimicking smallness', for instance using business units, subsidiaries or joint ventures. Because in colloquial speech many terms like entrepreneurs, self-employed and businessmen are used indiscriminately, its operationalization and measurement are far from obvious. However, one can make some pragmatic distinctions. First, between the concepts entrepreneurial, and managerial in the sense of organizing and coordinating. Second, between business-owners or self-employed (including owner-managers of incorporated firms) 5 and 
employees. Based on this double dichotomy of self-employed versus employee and entrepreneurial versus managerial, three types of entrepreneurs may be distinguished. These three types are the Schumpeterian entrepreneurs, the intrapreneurs and the managerial business owners who are entrepreneurs in a formal sense only. This is illustrated in Table 1.

Schumpeterian entrepreneurs are found mostly in small firms. They own and direct independent firms that are innovative and creatively destroy existing market structures. After realizing their goals Schumpeterians often develop into managerial business owners, but some may again start new ventures. Entrepreneurs or entrepreneurial managers also belong to the core of entrepreneurship. By taking commercial initiatives on behalf of their employer, and by risking their time, reputation and sometimes their job in doing so, they are the embodiment of leadership resulting in entrepreneurial ventures in larger firms. Sometimes these entrepreneurial employees, either in teams or on their own, spin off, start new enterprises and become Schumpeterian entrepreneurs.

Managerial business owners (entrepreneurs in a formal sense) are to be found in the large majority of small firms. They include many franchisees, shopkeepers and people in professional occupations. They belong to what Kirchhoff (1994) calls 'the economic core' and are the seedbed for some of the entrepreneurial ventures.

Table 1. Three types of entrepreneurs.

\begin{tabular}{|llc|}
\hline & Self-employed & Self- employed \\
\hline Entrepreneurial & Schumpeterian entrepreneurs & Entrepreneurs \\
Menagerie & Managerial business owners & Executive managers \\
\hline
\end{tabular}

Source: Wennekers and Thurik (1999)

\section{EXPERIMENTAL STUDIES}

Empirical evidence linking entrepreneurship (new business creation) to economic growth There are only a limited number of empirical studies devoted to the econometric link between economic growth at the national level and entrepreneurship in the form of new firm startups. This has been partly due to the difficulty in obtaining a measure of the national level of entrepreneurship that can be appropriately correlated to national economic growth as measured in terms of output, productivity or wealth. Much of studies have been done on the effect of entrepreneurship on economic growth, most of which used different variables such as human capital, physical capital, research and development costs, etc. in order to show the effect of entrepreneurship and innovation on economic growth.

In some of these studies, however, the entrepreneurship has not been directly pointed out, but the variables used by those studies are variables which show the amount of entrepreneurship and innovation index.

King et al, 1993, have studied the relationship between economic growth, entrepreneurship, and finance. In this study, he reviewed the effect of finance system on economic growth. They have used an endogenous growth model in which the forward-looking entrepreneurs' financial 
systems and equipping savings are evaluated so that the activities, having most probability of efficiency, are financed. This study comes to the conclusion that the better financing systems enhance the probability of creativeness success; thus they improve the economic growth, and similarly distortions of financial systems decrease the economic growth rate through decreasing creativeness rate.

Carree and Thurik $(1998,1999$ a) show that the share of small firms in manufacturing industries in European countries in 1990 has had a positive effect on the industry output growth in the subsequent four years. Thurik (1996) reports that the excess growth of small firms has had a positive influence on percentage change in gross national product for a sample of 16 European countries in the period 1988 through 1993.

Callejon and Segarra (1999) use a dataset of Spanish manufacturing industries between 1980 and 1992 to link new-firm birth rates and death rates (which, taken together, constitute a measure of turbulence) to total factor productivity growth in industries and regions. They adopt a model based on a vintage capital framework in which new entrants embody the available edge technologies and exiting businesses represent marginal obsolete plants. Using a Hall type of production function, which controls for imperfect competition and the extent of scale economies, they find that both new-firm startup rates and exit rates contribute positively to the growth of total factor productivity in regions as well as industries. Robbins et al. (2000) perform an analysis for 48 US states for 1986 through 1995 and find that states with a higher proportion of (very) small business employment experience higher levels of productivity growth and Gross State Product growth.

Robbins, Pantuosco, Parker and Fuller (2000) perform an analysis of 48 U.S. states for the 1986-95 period and find that states with a higher proportion of (very) small business employment experience higher level of productivity growth and Gross State Product growth. Acs and Armington (2002) link a measure of entrepreneurship to growth at the regional level. Their paper makes three important contributions.

First, their approach is more comprehensive, including data for the whole private sector economy, rather than selected industries. Second, their unit of analysis is not just cities, but entire local economic areas (394 Labor Market Areas, covering the entire United States), which generally include a metropolitan area and the surrounding rural area from which it draws both employees and consumers.

Third, they use a direct measure of entrepreneurial activity, the new firm birth rate in each of these local economies. They test the hypothesis that increased entrepreneurial activity leads to higher growth rates of local economies. They find that the higher levels of entrepreneurial activity are strongly positively associated with higher growth rates, even after controlling for establishment size, and agglomeration effects.

Audretsch, Carree, van Stel and Thurik (2002) find evidence for 17 European countries that the consequences for economic growth of not shifting the industry structure away from large business towards small business have been rather large. Likewise, Carree (2002) shows evidence for the five largest economies (France, Germany, Japan, U.K. and U.S.) those manufacturing industries that underwent only little downsizing in the 1977-90 period experienced less subsequent growth when compared internationally.

Nystrom (2008), in his study, reviewed the relationship between the economic freedom and entrepreneurship. He showed new evidences of factors effective on entrepreneurship, comparing 23 countries of OECD during the period 1972-2002. In this study, entrepreneurship was measured by measuring the amount of self-employment, and economic freedom was measured by five indexes of size of government, legal and security structure of ownership right, access to sound money, international business freedom and regulations related to the credits, 
manpower, and business. The experimental findings of this studies show that a smaller governmental section, a better ownership right, legal and security structure, and credits regulations, and less manpower and business cause an increase in entrepreneurship.

Rabiei (2009) have analyzed the effect of entrepreneurship and innovation on Iranian economic growth, using Romer Endogenous Growth Model, and considered a model for the Iranian economic growth which analyzes the effect of variables of labor, physical capital, human capital, research and development, and machinery import in proportion to the total machinery. The results of this study shows that intermediate goods, labor, human capital, physical capital, and machinery import, respectively, cause an increase in production in Iranian economy.

Minniti et al, 2010, has studied the effect of different kinds of entrepreneurship on economic growth. In this study, they focus on research costs, so that they have divided the entrepreneurship into two types of imitation-based entrepreneurship and research-based entrepreneurship. In their view, the current growth models have a strong focus on research and development costs. However, the economic growth observed in the past year in some countries such as China, in which the costs of research and development are not practically high, was significant, but in Japan that the costs of research and development are high, was not significant. They achieved to the result that when the costs of research and development are low, for example in new-found economics, presence of imitator entrepreneurs causes competition and sufficient production for economic growth; and economic growth is not so related to the type of entrepreneurship based on research or imitation-based entrepreneurship as well as research and development costs.

\section{DATA AND ECONOMETRIC METHODOLOGY}

This study aims to provide empirical evidence on the effect of entrepreneurship on economic growth for Sistan and Baluchestan Province. Entrepreneurship is a concept which has been investigated so far from different views. Everybody believes that it is motive power for the economic growth of developed and developing countries. However before going to estimate the data it is necessary to check the unit root presence in the data and for that in this study the ADF test is used in order to know the order of integration of the series. Annual time series variables data which utilized in this paper are include logarithm the ratio of Number of Exploitation Permit to Number of Establish Permit as a proxy to entrepreneurship (V) and logarithm Value Added in Industrial Sector, Labor employment in Industrial Sector, Physical Capital, compiled from various issues of the Statistical Yearbooks published by the Statistical Center of Iran. The transformation of the series to logarithms is intended to eliminate the problem of heteroskedasticity. Annual data for the period from $1978-2011$ are used in this study. We select these period because time series data on Variable are only available for this period in Sistan \& Baluchestan Province.

\section{FINDINGS AND DISCUSSION}

\section{1. Augmented Dickey-Fuller Unit Root Testing for order of integration}

Most of time series have unit root as many studies indicated including (Nelson and Polsser, 1982), and as proved by (Stock and Watson, 1988) and (Campbell and Perron, 1991) among others that most of the time series are non-stationary. 
The presence of a unit root in any time series means that the mean and variance are not independent of time. Conventional regression techniques based on non-stationary time series produce spurious regression and statistics may simply indicate only correlated trends rather than a true relationship (Granger and Newbold, 1974).

One of the most widely used unit root test is the Augmented Dickey-Fuller (ADF) unit root test (Dickey and Fuller, 1979, 1981). To this end, the Augmented Dickey-Fuller (ADF) test were carried out on the time series in levels and differenced forms. If we accept the null hypothesis that a time series is non-stationary (has at least one unit root), we then re-apply the procedures after transforming the series into the first differenced forms.

If the null hypothesis of non-stationary (when the time series is expressed in the first differenced form) can be rejected, we then may establish that the time series is integrated of order one. The number of the lags included was determined using Akaike Information Criteria (AIC).

Table 2. Augmented Dickey-Fuller Unit Root Test.

\begin{tabular}{ccc} 
Variable & $\begin{array}{c}\text { With } \\
\text { constant \& trend }\end{array}$ & $\begin{array}{c}\text { Without } \\
\text { Constant \& trend }\end{array}$ \\
& $-5.11^{*}$ & $-2.84^{*}$ \\
$\log (\mathrm{Y})$ & $-5.22^{*}$ & -3.36 \\
$\log (\mathrm{L})$ & $-3.70^{*}$ & $-3.40^{*}$ \\
$\log (\mathrm{K})$ & $-8.91^{*}$ & $-4.22^{*}$ \\
\hline
\end{tabular}

Note: $\mathrm{V}$ is entrepreneurship, $\mathrm{L}$ is employment in Industrial Sector, $\mathrm{K}$ is Physical Capital and $\mathrm{Y}$ is

Value Added in Industrial Sector .operator $(*)$, indicate the rejection of null hypotheses in a level of $5 \%$ respectively.

Table 2 reports the results for testing the null hypothesis of unit root using ADF tests with constant and time trend variables as well as without constant and time trend variables were included in the regression. As shown in Table 2, ADF test statistics in all cases we rejected the null hypothesis of unit root. Hence, we maintain the null hypothesis that each variable is integrated of order Zero or I(0).

\section{2. Econometrics Model}

The importance of human capital, generally, and training, particularity, in growth theories, had been focused in developed neo-classical model (MRW) and endogenous growth models, in the 1980s and 1990s. In the developed neo-classical model, the human capital is input to the model as an additional data, so the countries with the faster training growth, enjoy the higher rate of economic growth and income. In the endogenous growth model, training is considered as a process which changes the production technology, facilitates the conformity with the external technology, and makes the transfer of resources easy through the most dynamic and technologic sections.

One of the methods for quantitative estimation of such a research is using a production function, which is necessary for estimating interests of the costs incurred for training and increasing the human capital. There is, however, no special or definite method of how to apply human capital variable in the production function. 
In this study, we consider the production function as the Cobb-Douglas Function, in which the Value Added in Industrial Sector is a function of labor, inventory of the physical capital, entrepreneurship, and innovation:

$$
Y_{i}=A K_{i}^{\alpha} L_{i}^{\beta} V_{i}^{\gamma}
$$

where:

$Y i=$ Growth of Value Added in Industrial Sector

$L i=$ Labor

$K i=$ Physical Capital

$V i=$ Entrepreneurship Coefficient

$i=$ Innovation of the Country

$A=$ Technology Parameter and reflecting the production technology of each country and this fact that how each country can convert inputs to output.

$\alpha, \beta, \& \gamma=$ productive elasticity of physical capital, labor, and entrepreneurship and innovation, respectively, which are obtained as follows:

$$
\begin{gathered}
E_{Y_{i}, K_{i}}=\frac{d Y_{i}}{d K_{i}} \cdot \frac{K_{i}}{Y_{i}}=A \alpha K_{i}^{\alpha-1} L_{i}^{\beta} V_{i}^{\gamma} \cdot \frac{K_{i}}{Y_{i}}=A \alpha K_{i}^{\alpha-1} L_{i}^{\beta} V_{i}^{\gamma} \cdot \frac{K_{i}}{A K_{i}^{\alpha} L_{i}^{\beta} V_{i}^{\gamma}}=\alpha \\
E_{Y_{i}, L_{i}}=\frac{d Y_{i}}{d L_{i}} \cdot \frac{L_{i}}{Y_{i}}=A \beta K_{i}^{\alpha} L_{i}^{\beta-1} V_{i}^{\gamma} \cdot \frac{L_{i}}{Y_{i}}=A \beta K_{i}^{\alpha} L_{i}^{\beta-1} V_{i}^{\gamma} \cdot \frac{L_{i}}{A K_{i}^{\alpha} L_{i}^{\beta} V_{i}^{\gamma}}=\beta \\
E_{Y_{i}, V_{i}}=\frac{d Y_{i}}{d V_{i}} \cdot \frac{V_{i}}{Y_{i}}=A K_{i}^{\alpha} L_{i}^{\beta} V_{i}^{\gamma-1} \cdot \frac{V_{i}}{Y_{i}}=A \gamma K_{i}^{\alpha} L_{i}^{\beta} V_{i}^{\gamma-1} \cdot \frac{V_{i}}{A K_{i}^{\alpha} L_{i}^{\beta} V_{i}^{\gamma}}=\gamma
\end{gathered}
$$

The estimation of productive elasticity has the most useful indications for us which represent the manner and amount of effectiveness of the productive inputs on production and consequently in economic growth.

But the Cobb-Douglas Function is not a linear function, so, for estimating the productive elasticity, it should be converted to a linear function. For this purpose, we compute the logarithm of two members of this function:

So, our production function is converted to a linear function that the possibility of estimating their coefficient is obtained by using Ordinary Least Squares (OLS). The estimated coefficients are the productive elasticity of different inputs. 
Table 3. Estimated Coefficient.

\begin{tabular}{|ccc|}
\hline Dependent Variables & Estimated Coefficients & t Statistics \\
\hline $\boldsymbol{C}_{\boldsymbol{i}}$ & 12.21 & 4.32 \\
\hline $\boldsymbol{V}_{\boldsymbol{i}}$ & 0.60 & 2.72 \\
\hline $\boldsymbol{L}_{\boldsymbol{i}}$ & 0.92 & 2.53 \\
\hline $\boldsymbol{K}_{\boldsymbol{i}}$ & 0.38 & 3.92 \\
\hline$R^{2}=0.80$ & $\mathrm{~F}=9.57$ & $\mathrm{D}-\mathrm{W}=1.93$ \\
\hline
\end{tabular}

Resource: Research Findings

Also, F-Test (regression total meaningfulness test) indicates the model total meaningfulness in a level of 95 percent. The coefficient level of $R^{2}$ is 80 percent. This coefficient level indicates that about 80 percent of changes in gross domestic production could be explained by the variable introduced in the model. Durbin-Watson (D-W) statistic, which represents the presence or non-presence of autocorrelation, enjoys a suitable status, and the obtained number shows that there is no autocorrelation in the model.

\section{CONCLUSIONS}

In this paper, we are finding a relationship between entrepreneurship and Growth of Value Added in Industrial Sector. For this purpose, we investigated the data related to sistan and Baluchestan, Province in the period of 2000 to 2010 by using endogenous growth model. The obtained results show that there is a meaningful relationship between entrepreneurship and innovation and Growth of Added Value. The Growth of Value Added increases through raising entrepreneurship and innovation, in a manner that a one percent raises in the entrepreneurship coefficient would lead to a 0.60 percent raise in economic growth. Also, the obtained results show that the rate of Value Added increases through raising the physical capital and employed population, in a manner that a one percent raise in physical capital would lead to a 0.38 percent raise in Value Added and a one percent raise in the employed population would lead to a 0.92 percent raise in Added Value. In other words, productive elasticity of entrepreneurship and innovation, physical capital and labor is $0.60,0.38$, and 0.92 , respectively. The coefficient level of R2 is 80 percent. This coefficient level indicates that about 80 percent of changes in Growth of Value Added could be explained by the variable introduced in the model.

The results of this research, regarding the presence of a meaningful positive relationship between entrepreneurship and innovation and Growth of Added Value, are similar to the results of the most of studies, and are mentioned in the literature of the research. Based on the results of this paper, in addition to increasing physical capital and employment, the economic policymakers of the country should have an attention to the entrepreneurship and innovation as well as establishing conditions and suitable grounds in order to develop it, so the activities to be done for improving and promoting the entrepreneurship and innovation character should be considered as a useful investment which will result to an increase in Growth of Value Added and society welfare. 


\section{References}

[1] Acs Z. J., Challenge 35 (1992) 38-44.

[2] Acs Zoltan J., Catherine Armington (2002). "Entrepreneurial Activity and Economic Growth: An Empirical Analysis," Paper prepared for the Kaufman Foundation.

[3] Aghion P., P. Howitt, Econometrica 60 (1992) 323-351.

[4] Aghion P., P. Howitt (1997). A Schumpeterian perspective on growth and competition, in D.M. Kreps and K.F. Wallis (eds.), Advances in Economics and Econometrics: Theory and Applications, Vol. 2, Cambridge: Cambridge University Press, pp. 279-317.

[5] Aiginger K., G. Tichy, Small Business Economics 3 (1991) 83-101.

[6] Audretsch D. B. (1995). Innovation and Industry Evolution, Cambridge, MA: MIT Press.

[7] Audretsch D. B. (2000). Entrepreneurship in Germany, in D.L. Sexton and H. Landström (eds.), The Blackwell Handbook of Entrepreneurship, Oxford: Blackwell Publishers.

[8] Baumol W. J., American Economic Review 58 (1968) 64-71.

[9] Baumol W. J., Journal of Political Economy 98 (1990) 893-921.

[10] Baumol W. J., Journal of Business Venturing 8 (1993) 197-210.

[11] Berkowitz D., J. Holland, Economics Letters 74 (2001) 53-60.

[12] Carree M., A. van Stel, R. Thurik, S. Wennekers, Small Business Economics 19 (2002).

[13] Carree M. A., Small Business Economics 18 (2002) 243-255.

[14] Kristina N., Public Choice 136(3-4) (2008).

[15] Mahnaz R. (2010). Effect of Innovation and Manpower on Economic Growth in Iran. Knowledge and Development (Danesh va Tosee) Magazine, 16th year, Issue 26.

[16] Maria M., Moren L., Journal of Business Venturing 25(3) (2010).

[17] Norman A., Borrelli (2008). Education and economic growth in the United States: cross-national applications for an intra-national path analysis Policy.

[18] Robert G., King R. L., Journal of Monetary Economics 32(3) (1993).

[19] Michael P. Todaro, Stephen C. Smith, Economic Development. $10^{\text {th }}$ ed. Boston, MA: Addison Wesley, 2008. 